\title{
Physiological changes in reproductively active rainbowfish (Melanotaenia fluviatilis) following exposure to naphthalene
}

\author{
Carmel A. Pollino ${ }^{\mathrm{a}, *}$, Eugene Georgiades ${ }^{\mathrm{b}}$, Douglas A. Holdway ${ }^{\mathrm{c}}$ \\ a The Fenner School of Environment and Society, The Australian National University, Canberra ACT 0200, Australia \\ ${ }^{\mathrm{b}}$ Environmental Risk Management Authority, Wellington, New Zealand \\ ${ }^{\mathrm{c}}$ Faculty of Science, University of Ontario Institute of Technology, Oshawa, Ontario, Canada L1H 7K4
}

\section{A R T I C L E I N F O}

\section{Article history:}

Received 17 January 2008

Received in revised form

15 January 2009

Accepted 26 January 2009

Available online 14 March 2009

Keywords:

Rainbowfish

Naphthalene

Reproduction

EROD

\begin{abstract}
A B S T R A C T
Naphthalene makes up a substantial fraction of polycyclic aromatic hydrocarbons (PAHs) in crude oil and is an important by-product of industry; however, few studies have investigated the toxicity of naphthalene to aquatic organisms. We examined the toxicity of increasing concentrations ( 0 , carrier control, 130, 200 and $400 \mu \mathrm{g} / \mathrm{l}$ ) of naphthalene to adult rainbowfish (Melanotaenia fluviatilis) for 3 and 14 days to determine its potential to act as an endocrine disruptor. After exposure for 3 days, no changes in sex steroids were measured. After 14 days, a decrease of serum estradiol in females and an increase in serum testosterone in males was observed. These results suggest that naphthalene has the potential to act as an endocrine disruptor, although since no changes in plasma vitellogenin concentrations were observed in either sex, it is unlikely that naphthalene is acting as a xenoestrogen. There was a positive correlation between the incidences of deformities in larval offspring with increasing naphthalene concentrations, suggesting parental transfer of the toxicant. Egg production, hatchability and larval lengths remained unaltered, whilst few changes were measured in $\gamma$-glutamyltranspeptidase (GTP), an enzymatic indicator of spermatogenesis. Contrary to other PAHs, hepatic ethoxyresorufin-O-deethylase (EROD) activities declined with increasing exposure concentration, suggesting that naphthalene was either having a cytotoxic effect or disrupting enzyme synthesis.
\end{abstract}

(C) 2009 Elsevier Inc. All rights reserved.

\section{Introduction}

The majority of studies investigating the toxicity of polycyclic aromatic hydrocarbons (PAHs) have tended to focus on benzo(a)pyrene. Like benzo(a)pyrene, naphthalene is released into the environment from both point and non-point sources. Up to $1.5 \%$ of crude oil is made up of PAHs, of which 65\% is made up of naphthalene and its derivatives. Naphthalene is abundant in coal and coal tar, and is produced from coal tar fractions by crystallisation and distillation (Gavin et al., 1996). Release of naphthalene occurs during wastewater disposal from chemical production processes, refineries and oil production, and due to leaching of treated wood products (Gavin et al., 1996). Non-point source releases of naphthalene are from traffic, gasoline and lubricants, and boat traffic. Consequently, naphthalene is commonly found in soils, sediments, surface water and groundwater (Kanga et al., 1997).

Naphthalene is one of the lighter PAHs, being only a di-aromatic hydrocarbon and having a low molecular weight PAH (molar mass $=128.171 \mathrm{~g} / \mathrm{mol}$ ). Consequently, naphthalene is

\footnotetext{
* Corresponding author.

E-mail address: carmel.pollino@anu.edu.au (C.A. Pollino).
}

highly volatile. It is a non-polar compound, with an octanol-water partition coefficient of $\log K_{\mathrm{ow}} 3.01-3.45$, suggesting that it is moderately hydrophobic, having a tendency to adsorb to particulate matter, including soils and sediments, and may potentially accumulate in biota. In Australia, little information is available regarding ambient concentrations of naphthalene in the environment. Only very low concentrations of between 19 and $26 \mathrm{ng} / \mathrm{l}$ were found in the Brisbane River estuary (Kayal and Connell, 1989). Given the physical characteristics of naphthalene and low emissions of naphthalene from industry, we have found that it is unlikely to reach high concentrations in freshwater systems and cause acute toxicity (Pollino and Holdway, 2002b). However, there is little information describing the risk of fish populations in areas of chronic contamination and in the vicinity of an oil spill.

PAHs have been identified as potential endocrine disruptors (Cooper and Kavlock, 1997). Evidence of this has been found in a previous study where exposure to PAHs caused a decline in estradiol in the flounder (Platichthys flesus) (Monteiro et al., 2000), possibly due to a reduction in the conversion of testosterone to estradiol, as mediated by aromatase. Similarly, exposure of the Atlantic croaker (Micropogonias undulatus) to naphthalene alone (reported as 0.5 and $1.0 \mathrm{ppm}$ ) and water-soluble fraction of crude oil (reported as $2.5 \%$ and $5.0 \%$ water-soluble fraction) blocked sexual maturation and impaired ovarian recrudescence, with a 
decline in plasma level of gonadal hormones following naphthalene exposure (Thomas and Budiantara, 1995). An assay measuring in vitro germinal vesicle breakdown found that some of naphthalene's reproductive toxicity was due to either membrane damage or interference with hormone membrane receptors on target tissues. Orally administered naphthalene was found to accumulate in the ovaries of the spawning English sole (Parophrys vetulus) (Reichert and Varanasi, 1982). A more recent study by Tintos et al. (2007) also found a decline in plasma estradiol following injections of naphthalene to rainbow trout (Oncorhynchus mykiss). In addition, previous studies have found that PAH exposure of fish can alter the survival and viability of their offspring (Hose et al., 1981).

The mediating factors for determining the toxicity of PAHs to fish are the exposure level, the rate of metabolism of the parent compound and the form of the metabolite, as enzymatically transformed PAHs are often more toxic than the parent compound. Metabolism of PAHs occurs predominantly via the cytochrome P450 family of detoxification enzymes. Studies with benzo[a]pyrene have demonstrated the potential for induction of the cytochrome P4501A (CYP1A1) detoxification enzymes to be induced on exposure and for toxicologically active derivatives to be formed (Wu et al., 2003). The biotransformation of PAHs can increase CYP1A activity by 10-100 times (Livingstone, 1998). Although no mechanistic links between the cytochrome P450mediated metabolism of PAHs and adverse effects on reproduction have been established, other studies have established a relationship between detoxification enzyme activity and adverse reproductive effects (Meucci and Arukwe, 2006; Arukwe et al., 2008).

In this study, we investigated the effect of naphthalene exposure on reproductive variables of the adult crimson-spotted rainbowfish (Melanotaenia fluviatilis; also referred to as the Murray rainbowfish) using a range of bioindicators. Biochemical reproductive parameters measured were estradiol, testosterone, plasma vitellogenin and $\gamma$-glutamyltranspeptidase (GTP) and organism reproductive indicators were egg production, egg hatchability and larval lengths. GTP enzymes have a role in spermatogenesis and are often used as indicator of dysfunction in mammals (Kumar et al., 2000). GTP enzymes have been successfully used as an indicator of testicular activity in fish, specifically the male eelpout (Zoaces viviparous) (Christiansen et al., 1998) and the crimson-spotted rainbowfish (M. fluviatilis) (Pollino and Holdway, 2003; Pollino et al., 2007). The ethoxyresorufinO-deethylase (EROD), a catalytic measure of cytochrome P4501A induction, was measured to determine whether enzyme activity could be related to reproductive parameters. We have shown previously that crimson-spotted rainbowfish (Pollino et al., 2007) are a suitable indicator species for endocrine disruption.

\section{Materials and methods}

The crimson-spotted rainbowfish, $M$. fluviatilis, was used as the experimental animal in this study. We assure that our study was conducted in accordance with university, State and international (American Fisheries Society, 2004 American Fisheries Society, VIII. Storage or disposition of experimental animals: euthanasia. In: American Fisheries Society, Editor, Guidelines for the Use of Fishes in Research, American Fisheries Society, Bethesda, Maryland (2004)) guidelines for the protection of human subjects and animal welfare.

Nominal naphthalene exposure concentrations were 0,0 (CC), 320, 560 and $1000 \mu \mathrm{g} / \mathrm{L}$. These concentrations are likely to be higher than found in the environment; however, generally little monitoring information is available regarding ambient naphthalene concentrations, including after an oil spill. Naphthalene was introduced to solutions using ethanol as a carrier. A volume of $100 \mu \mathrm{L} / \mathrm{L}$ was used for carrier controls (CC) and exposure concentrations, meeting standard guideline requirements (ASTM, 2006). Exposures were conducted as 50\% static replacement tests and were conducted in quadruplicate. Samples for analysing test solution concentrations were collected prior to, and following solution replacement.

Naphthalene concentrations were measured in water samples using a UV spectrophotometer (Cary 50, Varian), and water samples were analysed within $1 \mathrm{~h}$ of collection. Test solutions $(3 \mathrm{~mL})$ were placed in a quartz cuvette and measured at $220 \mathrm{~nm}$ (Stene and Lonning, 1985) and solution concentrations were calculated from a standard curve prepared daily. Mean (SE) test concentrations used were 0 (0), 0 (0) (CC), 130 (39.2), 200 (49.9) and $400(43.1) \mu \mathrm{g} / \mathrm{L}(n=28)$. Mean $( \pm \mathrm{SE}) \mathrm{pH}$, dissolved oxygen, conductivity and temperature measurements were 7.0 (0.2), $6.1 \mathrm{mg} / \mathrm{L}(0.7), 109 \mu \mathrm{S}(11)$ and $24.8^{\circ} \mathrm{C}(0.3)$, respectively.

Rainbowfish stock was originally collected from the Murray River in Victoria (Australia). The laboratory stock was the fifth generation removed from the wild and was maintained at the RMIT-University wet laboratory. Adult rainbowfish were fed twice daily on three types of feed: commercial flake, newly hatched live brine shrimp and frozen adult brine shrimp. The water and room temperature were maintained at $25^{\circ} \mathrm{C}$. Rainbowfish are sexually dimorphic. Groups $(n=20)$ of 2 male and 3 female sexually mature adult fish were randomly assigned to one of twenty $28 \mathrm{~L}$ glass aquaria. This ratio of sexes has been used as a standard in previous studies using this species. The weight of female fish ranged between 3 and $5 \mathrm{~g}$, whilst males ranged between 6 and $8 \mathrm{~g}$. Lengths of females ranged from 3.3 to $5.3 \mathrm{~cm}$ and males ranged from 4.2 to $6.0 \mathrm{~cm}$. Replicates A and B were sampled after 3 days of exposure, while replicates $C$ and $D$ were sampled after 14 days of exposure. The aquaria were aerated.

Total egg numbers were counted daily throughout the exposure period. Artificial plastic spawning grass substrates were placed in each tank for collection of eggs. Eggs were collected by hand, counted and dipped in $4 \mathrm{mg} / \mathrm{L}$ malachite green for $5 \mathrm{~min}$ to prevent fungal growth (Pollino and Holdway, 2003b). Eggs were distributed to Petri dishes and randomly placed in an incubator maintained at $25^{\circ} \mathrm{C}$. Dead eggs were removed up until hatch and the developmental stages and state of embryos were recorded. Post-hatch, the percentage hatch was calculated and larval lengths were measured using a Wild binocular microscope.

Adults were sampled for blood and tissues at days 3 and 14 for biochemical analyses. Fish were anaesthetized using Tricaine Methane Sulphonate ([MS-222] Sigma-Aldrich, Castle Hill, NSW, Australia). Blood was collected by caudal severance using heparinised capillary tubes. Fish were then euthanized by spinal severance. Blood was centrifuged at $2500 \mathrm{~g}$ and the plasma was collected and stored at $-80^{\circ} \mathrm{C}$. Serum was collected for measurement of vitellogenin and steroids. Testes were collected for $\gamma$-GTP analyses and livers for EROD analyses. Tissues were frozen in liquid nitrogen and stored at $-80^{\circ} \mathrm{C}$.

Unless otherwise stated, all chemicals were purchased from Sigma-Aldrich (Castle Hill, NSW, Australia).

\subsection{Vitellogenin methodology}

Vitellogenin was measured using the alkali-labile protein phosphorous method (phosphoprotein), which has been shown to be a reliable indicator of vitellogenin (Kramer et al., 1998). The assay was optimised for rainbowfish (Pollino and Holdway, 2003a). The plasma volume used for the assay was $10 \mu \mathrm{L}$. To isolate vitellogenin, $2.5 \mathrm{~mL}$ of $10 \%$ trichloroacetic acid was added to $10 \mu \mathrm{L}$ of plasma overnight and the precipitate was collected centrifugally. The precipitate was incubated in $5 \%$ trichloroacetic acid for $30 \mathrm{~min}$ at $90^{\circ} \mathrm{C}$ and washed successively with hot absolute alcohol, chloroform-ether-alcohol (1:2:2), acetone and ether The precipitate was dissolved and incubated at $100{ }^{\circ} \mathrm{C}$ in $0.5 \mathrm{~mL} 2 \mathrm{~N} \mathrm{NaOH}$ and neutralised with an equivalent amount of concentrated $\mathrm{HCl}$. Ortho-phosphate concentration was determined by the colourimetric assay of the acidified phosphomolybdate complex using a commercial kit (Sigma Cat. No. 670-A, Australia). Using a spectrophotometer, absorbance was measured at $660 \mathrm{~nm}$ (Varian, Mountain View, CA, USA) within $10 \mathrm{~min}$ of colour development.

\subsection{Sex steroids methodology}

Sex steroids were measured via radioimmunoassay (Fitzpatrick et al., 1986). Radiolabels that were purchased from Amersham (Buckinghamshire, UK) and antibodies were supplied by Colorado State University (Fort Collins, CO, USA).

Estradiol was measured in females and testosterone was measured in males. Each plasma sample $(25 \mu \mathrm{L})$ was extracted twice with diethyl ether $(2 \mathrm{~mL})$. Extracts were combined and reconstituted. Antibody $(100 \mu \mathrm{L})$ was added to all tubes except total count and non-specific binding tubes. Each tube received the appropriate antibody dilution as optimised previously (Pollino and Holdway, 2002a). Tubes were incubated overnight at $4{ }^{\circ} \mathrm{C}$ with tritiated steroid $(100 \mu \mathrm{L}, 10,000 \mathrm{cpm})$ in buffer $\left(1,2,6,7,16,17-{ }^{3} \mathrm{H}\right.$ estradiol, $1,2,6,7-{ }^{3} \mathrm{H}$ testosterone). Following incubation, cold well-mixed dextran-coated charcoal suspension $(0.5 \mathrm{~mL}$ for estradiol and $1 \mathrm{~mL}$ for testosterone) was added to all tubes, except for the total count tubes. Tubes were incubated in an ice bath for $10 \mathrm{~min}$, and then centrifuged. The sample liquid $(500 \mu \mathrm{L})$ was decanted into scintillation vials with $5.2 \mathrm{~mL}$ of scintillation cocktail and counted in a scintillation spectrophotometer (Packard Instrument Company Inc., Meriden, CT, USA). 


\subsection{GTP methodology}

The methodology for GTP analysis was adapted for rainbowfish as detailed in Pollino and Holdway (2002a). To isolate the enzyme, a sample of between 25 and $35 \mathrm{mg}$ wet weight of testis was weighed, homogenised (Heidolph DIAX 900, Germany) in phosphate buffer and centrifuged. The supernatant was collected and assayed for GTP using MPR2 kit (Boehringer Mannheim, Germany). A change in absorbance was measured at $410 \mathrm{~nm}$ over $5 \mathrm{~min}$ using a UV spectrophotometer (Varian, Mountain View, CA, USA).

\subsection{EROD methodology}

Hepatic EROD was measured using the procedure of Burke and Mayer (1974), as modified for rainbowfish by Pollino and Holdway (2003b). Briefly, the postmitochondrial supernatant was prepared in $0.1 \mathrm{M}$ phosphate buffer, which contained $1 \mathrm{mM}$ dithiothreitol, $1 \mathrm{mM}$ EDTA, $0.1 \mathrm{M}$ potassium chloride and $0.1 \mathrm{M}$ phenanthroline. The homogenate was centrifuged at $10,000 \mathrm{~g}$ for $20 \mathrm{~min}$ in the Beckman TLX benchtop ultracentrifuge. The supernatant was collected and stored at $-80^{\circ} \mathrm{C}$ for no longer than 7 days. Test and blank tubes were prepared containing $500 \mu \mathrm{L}$ of $0.1 \mathrm{M}$ Tris buffer, $250 \mu \mathrm{L}$ of $\mathrm{NADPH}$ regenerating system, $50 \mu \mathrm{L}$ of supernatant and $100 \mu \mathrm{L}$ of $12 \mathrm{mg} / \mathrm{mL}$ albumin. A volume of $0.1 \mathrm{~mL}, 0.01 \mathrm{mM}$

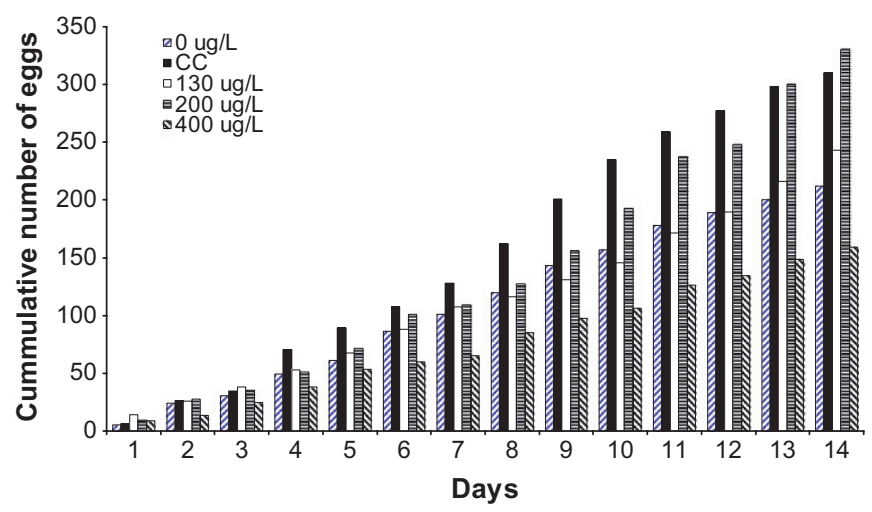

Fig. 1. The number of eggs produced prior to and each day of the 14-day exposure period. ethoxyresorufin was added to start the reaction and maintained at $30^{\circ} \mathrm{C}$ for $10 \mathrm{~min}$. The reaction was stopped with methanol and fluorescence was measured with a spectrofluorimeter (Hitachi, F-4500) at excitation wavelength $530 \mathrm{~nm}$ and emission wavelength $585 \mathrm{~nm}$.

\subsection{Determination of protein concentration}

Protein concentrations were determined according to Lowry et al. (1951).

\subsection{Statistical analyses}

All statistics were performed using the statistical software Statistica (Statsoft, USA). Data were assessed for normality and homogeneity of variance. Non-normal data were transformed as required. Analysis of variance (ANOVA) and Dunnett's test was used to determine significance $(p \leqslant 0.05)$ between samples (Zar, 1999).

\section{Results}

\subsection{Egg production and larval fitness}

Although cumulative egg production was reduced at the highest test concentration, these changes were not statistically significant (Fig. 1). Despite hatchability being unchanged, larval deformities were observed in the offspring (Table 1). The percentage of deformed larvae increased over the 14-day exposure period. The major deformities observed were pericardial edema, although some larvae (approximately 10\%) also had spinal deformities (Fig. 2). There were no differences in the larval lengths recorded throughout the exposure period (results not shown).

\subsection{Sex steroids, vitellogenin and $\gamma$-GTP}

Both estradiol in females and testosterone in males were altered as a result of the exposure to naphthalene (Table 2). Although there were no changes in plasma estradiol at day 3 ,

Table 1

Reproductive and biochemical parameters of adult rainbowfish following 3 and 14 days of exposure to various concentrations of naphthalene.

\begin{tabular}{|c|c|c|c|c|c|}
\hline & \multicolumn{5}{|c|}{ Naphthalene concentration $(\mu \mathrm{g} / \mathrm{L})$} \\
\hline & 0 & $\mathrm{CC}$ & 130 & 200 & 400 \\
\hline \multicolumn{6}{|l|}{ Day 3} \\
\hline Estradiol (f) & $483(52.1)^{a}$ & $319(32.4)^{\mathrm{ac}}$ & $489(85.0)^{\mathrm{a}}$ & $300(84.9)^{\mathrm{ac}}$ & $404(134)^{a}$ \\
\hline Testosterone (m) & $287(46.8)^{a}$ & $200(23.16)^{\mathrm{ab}}$ & $135(25.0)^{\mathrm{b}}$ & $231(39.0)^{\mathrm{ab}}$ & $201(50.5)^{\mathrm{ab}}$ \\
\hline Phosphoprotein (f) & $10.2(2.07)^{\mathrm{a}}$ & $6.58(1.23)^{\mathrm{abc}}$ & $7.23(1.78)^{\mathrm{abc}}$ & $5.30(0.42)^{\mathrm{bcd}}$ & $7.23(1.54)^{\mathrm{abc}}$ \\
\hline Phosphoprotein (m) & $4.85(0.41)^{\mathrm{bcd}}$ & $4.43(1.13)^{\mathrm{bcd}}$ & $4.76(1.18)^{\mathrm{bcd}}$ & $8.53(1.97)^{\mathrm{ad}}$ & $5.97(0.76)^{\mathrm{ac}}$ \\
\hline $\mathrm{GTP}(\mathrm{m})$ & $2770(1120)^{a}$ & $2610(1630)^{\mathrm{a}}$ & $3060(1620)^{a}$ & $5490(2300)^{\mathrm{b}}$ & $5870(1930)^{\mathrm{b}}$ \\
\hline EROD (f) & $185(42.9)^{\mathrm{a}}$ & $165(63.3)^{a}$ & $180(37.5)^{\mathrm{a}}$ & $226.0(51.74)^{a}$ & $130(40.4)^{\mathrm{a}}$ \\
\hline EROD $(\mathrm{m})$ & $264(59.9)^{a}$ & $326(17.9)^{\mathrm{a}}$ & $434(31.0)^{a}$ & $246(42.7)^{a}$ & $192(16.2)^{\mathrm{a}}$ \\
\hline \multicolumn{6}{|l|}{ Day 14} \\
\hline Estradiol (f) & $423(73.9)^{\mathrm{a}}$ & $334(61.4)^{\mathrm{ad}}$ & $197(39.1)^{\mathrm{bc}}$ & $189(24.9)^{\mathrm{bc}}$ & $203(38.0)^{\mathrm{bc}}$ \\
\hline Testosterone (m) & $221(7.49)^{\mathrm{ab}}$ & $283(41.8)^{a}$ & $239(46.2)^{\mathrm{ab}}$ & $149(79.8)^{\mathrm{ab}}$ & $449(21.4)^{c}$ \\
\hline Phosphoprotein (f) & $9.12(0.72)^{\mathrm{abc}}$ & $11.5(1.02)^{\mathrm{a}}$ & $5.78(1.54)^{\mathrm{ce}}$ & $7.58(1.11)^{\mathrm{abc}}$ & $8.83(0.64)^{\mathrm{a}}$ \\
\hline Phosphoprotein (m) & $3.31(0.63)^{\mathrm{bc}}$ & $5.24(0.69)^{\mathrm{bcd}}$ & $3.46(0.64)^{\text {bef }}$ & $7.92(2.79)^{\mathrm{abc}}$ & $3.94(0.15)^{\mathrm{cf}}$ \\
\hline$\gamma$-GTP $(\mathrm{m})$ & $3090(1610)^{a}$ & $3310(1300)^{\mathrm{ab}}$ & $4420(2280)^{\mathrm{ab}}$ & $3930(2590)^{\mathrm{ab}}$ & $3910(2130)^{\mathrm{ab}}$ \\
\hline EROD (f) & $66.2(5.11)^{a}$ & $91.4(6.18)^{a}$ & $38.7(8.12)^{a}$ & $25.7(4.61)^{b}$ & $6.24(1.55)^{b}$ \\
\hline EROD (m) & $321(66.4)^{a}$ & $224(25.9)^{a}$ & $110(41.8)^{b}$ & $94.1(23.7)^{b}$ & $38.6(9.62)^{b}$ \\
\hline
\end{tabular}

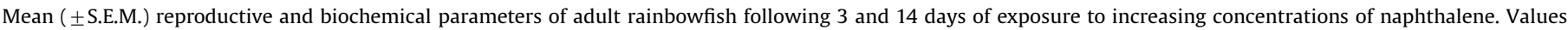

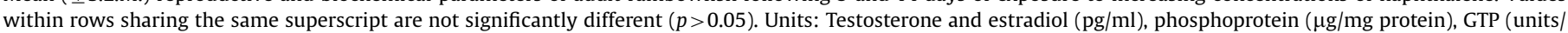
$\mathrm{mg}$ protein), EROD ( $\mathrm{pmol} / \mathrm{min} / \mathrm{mg}$ protein), $\mathrm{f}=$ female, $\mathrm{m}=$ male. 

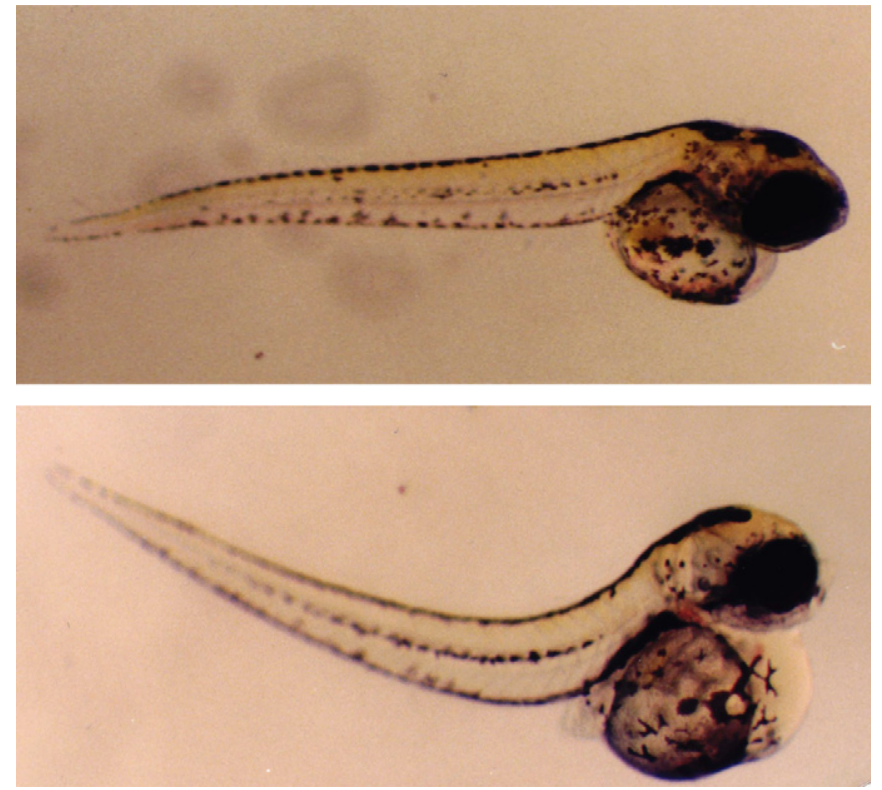

Fig. 2. One-day-old rainbowfish showing (A) a normal larvae and (B) larvae with a heart edema and spinal deformity.

Table 2

Percentage of hatched larvae, showing the contribution of larvae with deformities in brackets.

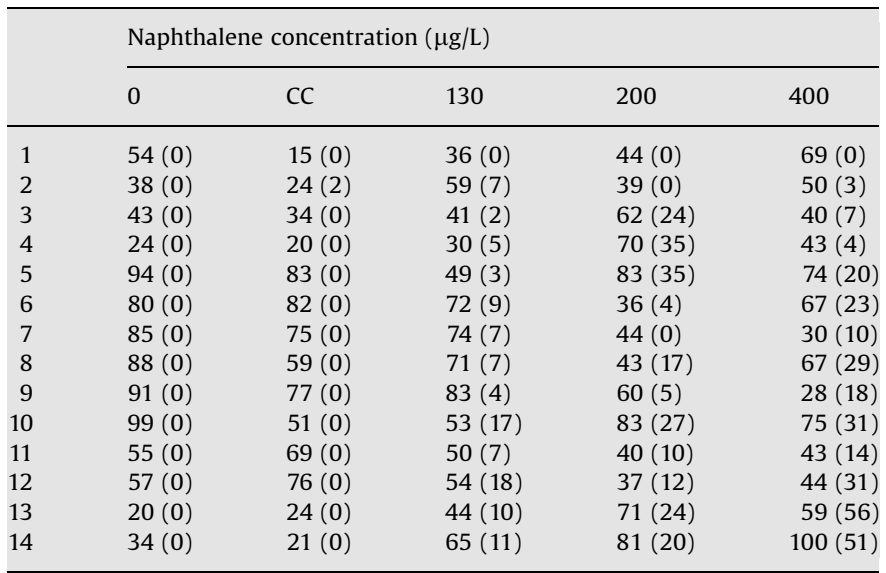

Mean percentage hatchability of eggs produced over the exposure period. The figures in brackets represent the mean percentage of abnormal larvae of the percentage hatched eggs.

concentrations were decreased following 14 days of exposure to all test solutions. Similarly, no changes in testosterone concentrations were measured after 3 days of exposure. By contrast, after 14 days of exposure plasma testosterone was increased at $400 \mu \mathrm{g} / \mathrm{L}$. There was little variation in control estradiol and testosterone concentrations over the exposure period.

No significant differences in plasma vitellogenin concentrations for male or female fish were observed at either of the sample periods. Female concentrations were generally higher than males (Table 2).

$\gamma$-GTP concentrations in male fish were significantly higher at 200 and $400 \mu \mathrm{g} / \mathrm{L}$ after 3 days of exposure to naphthalene (Table 2). By contrast, there were no significant differences between exposure groups at day 14 .

\section{3. $E R O D$}

After 3 days of naphthalene exposure, no significant changes in EROD activities were observed in female or male fish (Table 2). However, following 14 days naphthalene exposure females had lower EROD activities at the two highest exposure concentrations, 200 and $400 \mu \mathrm{g} / \mathrm{L}$, and males had lower activities at all test concentrations.

\section{Discussion}

If gametes and early life stage fish are exposed to toxicants, general developmental mechanisms may be disrupted. This can lead to abnormal cell or tissue differentiation, excessive or inadequate cell death during development, inadequate cell movement, improper cell communication and/or disrupted metabolism (Weis and Weis, 1989). In our study, an increase in larval spinal flexures and pericardial edema occurred. Pericardial edema may result from ionic disturbances and a toxic response from metabolic activation of PAHs in the embryo (Carls et al., 1999). Exposures of $0.85 \mathrm{mg} / \mathrm{L}$ naphthalene to fathead minnows (Pimephales promelas) have been shown to cause a reduction in hatchability and depressed growth of fry (DeGraeve et al., 1982). Although naphthalene was found to be non-lethal to inland silverside (Menidia beryllina) embryos, teratogenic effects were observed (Middaugh et al., 1988).

Maternal transfer of toxicants has been shown to cause malformations and edemas post-hatch as well as to increase the sensitivity of offspring to stress (Billsson et al., 1998). Although early life stage of rainbowfish were exposed to waterborne naphthalene for up to $24 \mathrm{~h}$ prior to collection, parental transfer of toxicants was likely to be causing part of the observed toxicity to larvae, as the incidence of larval deformities increased over the 2-week exposure period. Naphthalene has been shown to accumulate in the ovaries of English sole (P. vetulus) (Reichert and Varanasi, 1982). As ovarian tissues can bioaccumulate naphthalene, and yolk reserves are highly lipophilic, the potential for the maternal transfer exists.

In mature fish, PAH exposure has been shown to alter in steroid levels. Tintos et al. (2007) observed in rainbow trout where plasma levels of both cortisol and estradiol were reduced following injections and implants of 10 and $50 \mathrm{mg} / \mathrm{kg}$ naphthalene. Exposure of Atlantic croaker (M. undulatus) to benzo(a) pyrene also caused a decline in plasma estradiol (Thomas, 1990). Declines in vitellogenin levels, impaired steroidogenesis and decreased ovarian growth were also observed (Thomas, 1990). Female sole ( $P$. vetulus) captured at sites contaminated with naphthalene also had depressed plasma levels of estradiol, which coincided with induced aryl hydrocarbon hydroxylase activities, as a measure of cytochrome P4501A activity (Johnson et al., 1988). Likewise, in rainbowfish naphthalene caused a decline in estradiol; however, EROD activities were reduced and vitellogenin was unchanged in both sexes.

Given the role of the liver in both sexual maturation and xenobiotic metabolism (Aruwke et al., 2000), changes in reproductive parameters are likely to be associated with changes with hepatic detoxification processes, including the cytochrome P450 system. Many studies have shown that alterations in P450 enzyme activities coincide with changes to the reproductive success of fish, having both anti-estrogenic and estrogenic outcomes (Thomas, 1990; Meucci and Arukwe, 2006; Arukwe et al., 2008). As male rainbowfish did not have any changes in vitellogenin production, naphthalene is unlikely to be acting as a xenoestrogen. Given the measured hormonal changes, being reductions in estradiol and increases testosterone, naphthalene is more likely to 
be acting as an anti-estrogenic compound. Although EROD activities were unchanged in rainbowfish after 3 days of exposure to naphthalene, following 14 days of exposure EROD activity was inhibited at all exposure concentrations. Inhibition of EROD activity could have been the result of cytotoxic effects, where the synthesis of new enzymes is disrupted (Steadman et al., 1991).

The anti-estrogenic action of P450-inducing compounds could also disrupt vitellogenin synthesis and egg production (Anderson et al., 1996). With a decline in estradiol, decreased liver synthesis of vitellogenin during the pre-vitellogenic and vitellogenic reproductive period in female fish would result in reduced plasma vitellogenin and subsequently regressed ovaries and reduced egg production. Following the exposure of rainbowfish to naphthalene in this study, no changes in egg production, vitellogenin or structural organisation of the ovaries were found. Further studies are required to investigate the effects of a longer exposure duration.

Unlike the decline in estradiol observed in female fish, an increase in plasma testosterone in rainbowfish males was measured at $400 \mu \mathrm{g} / \mathrm{L}$. Alterations in the concentrations of plasma sex steroids may be related to disturbances in the cytochrome P450 enzyme, aromatase, which catalyses the conversion of androgens to estrogen. Males convert testosterone to estradiol in the testis. As discussed, cytochrome P450 enzymes can be disrupted by naphthalene, disturbing steroid homeostasis. Inhibition of aromatase could explain the lack of conversion of testosterone to estradiol, with reduced estradiol and increased testosterone being observed in female and male rainbowfish, respectively. Monteiro et al. (2000) found that the aromatase enzyme is inhibited by PAHs resulting in a decrease in estradiol synthesis. Further study is required to definitively decide whether naphthalene is inhibiting aromatase. GTP activities suggest that spermatogenesis was not disrupted by short-term exposures to naphthalene.

Whether the link between cytochrome P450 enzyme activities and reproductive parameters (in particular estradiol) is causal or correlative requires further investigation. The results of our study show that naphthalene is likely to be acting as an anti-estrogenic compound to rainbowfish, although further studies are required to definitively identify the mechanism and to determine whether the fitness of offspring from exposed parents is likely to decrease.

\section{Conclusion}

Naphthalene compounds are major components of PAHs in crude oil. Naphthalene is also found in produced water, the byproduct of oil and gas production. The measured concentration of naphthalene in produced water was $133 \mu \mathrm{g} / \mathrm{L}$ (Middaugh et al., 1988), which is within the concentration range in this study causing toxic effects. The environmental hazard report by Gavin et al. (1996) concluded that under normal situations naphthalene was unlikely to cause adverse environmental effects. However, measured levels in heavily contaminated sites may have adverse effects on the aquatic environment. Although the naphthalene concentrations examined in this study are likely to be found only at chronically polluted sites or those following an oil spill, the results confirm that naphthalene can have a negative impacts on fish reproduction at heavily contaminated sites.

\section{Acknowledgments}

The authors wish to acknowledge M. Fitzgerald, D. Kime and G. Niswender (Colorado State University) for providing antisera and anonymous reviewer comments that improved the manuscript. An Australian Postgraduate Award to C. Pollino and an ARC large grant (A00000256) to D.A. Holdway supported this research.

\section{References}

Anderson, M., Miller, M., Hinton, D., 1996. In vitro modulation of 17-beta-estradiolinduced vitellogenin synthesis: effects of cytochrome P4501 A1 inducing compounds in rainbow trout (Oncorhynchus mykiss) liver cells. Aquat. Toxicol. $34,327-350$.

Arukwe, A., Nordtug, T., Kortner, T.M., Mortensen, A.S., Brakstad, O.G., 2008. Modulation of steroidogenesis and xenobiotic biotransformation responses in zebrafish (Danio rerio) exposed to water-soluble fraction of crude oil. Environ. Res. 107, 362-370.

Aruwke, A., Celius, T., Walther, B., Goksoyr, A., 2000. Effects of xenobiotic treatment on zona radiata protein and vitellogenin expression in Atlantic salmon (Salmo salar). Aquat. Toxicol. 49, 159-170.

ASTM, 2006. Standard Guide for Conducting Acute Toxicity Tests with Fishes, Macroinvertebrates, and Amphibians. American Society for Testing and Materials, Philadelphia, pp. 79-100.

Billsson, K., Westerlund, L., Tysklind, M., Olsson, P., 1998. Developmental disturbances caused by polchlorinated biphenyls in Zebrafish (Brachydanio rerio). Mar. Environ. Res. 46, 461-464.

Burke, M., Mayer, R., 1974. Ethoxyresorufin: direct fluorimetric assay if a microsomal $O$-dealkylation which is preferentially inducible by 3-methylcholanthrene. Drug Metab. Disposit. 2, 583-588

Carls, M., Rice, S., Hose, J., 1999. Sensitivity of fish embryos to weathered crude oil: part I. Low-level exposure during incubation causes malformations, genetic damage, and mortality in larval Pacific herring (Clupea pallasi). Environ. Toxicol. Chem. 18, 481-493.

Christiansen, T., Korsgaard, B., Jespersen, A., 1998. Effects of nonylphenol and 17B-oestradiol on vitellogenin synthesis, testicular structure and cytology on male eelpout zoarces viviparus. J. Exp. Biol. 201, 179-192.

Cooper, R.L., Kavlock, R.J., 1997. Endocrine disruptors and reproductive development: a weight-of-evidence overview. J. Endocrinol. 152, 159-166.

DeGraeve, G., Elder, R., Woods, D., Bergman, H., 1982. Effects of naphthalene and benzene on fathead minnows and rainbow trout. Arch. Environ. Contam. Toxicol. 11, 487-490.

Fitzpatrick, M., Van Der Kraak, G., Schreck, C., 1986. Profiles of plasma sex steroids and gonadotrpin in coho salmon, Oncorhynchus kisutch, during final maturation. Gen. Comp. Endocrinol. 62, 437-451.

Gavin, M., Brooke, D., Howe, P., Dodson, S., 1996. Environmental Hazard Assessment: Naphthalene. TSD/27, Chemicals and Biotechnology Division, Department of Environment, Garston, Watford.

Hose, J., Hannah, J., Landolt, M., Miller, B., Felton, S., Iwaoka, W., 1981. Uptake to benzo(a)pyrene by gonadal tissue of flatfish (family Pleuronecte) and its effects on subsequent egg development. J. Toxicol. Environ. Health 7, 991-1000.

Johnson, L., Casillas, E., Collier, T., McCain, B., Varanasi, U., 1988. Contaminant effects of ovarian development in English sole (Parophrys vetulus) from puget sound, Washington. Can. J. Fish Aquat. Sci. 45, 2133-2146.

Kanga, S., Bonner, J., Page, C.M., Mills, M., Autenreith, R., 1997. Solubilization of naphthalene and methyl-substituted naphthalene from crude oil using biosurfactants. Environ. Sci. Technol. 31, 556-561.

Kayal, S., Connell, D., 1989. Occurrence and distribution of polycyclic aromatic hydrocarbons in surface sediments and water from the Brisbane River estuary, Australia. Estuar. Coast. Shelf Sci. 29, 473-487.

Kramer, V.J., Miles-Richardson, S., Pierens, S.L., Giesy, J.P., 1998. Reproductive impairment abd induction of alkaline-labile phosphate, a biomarker of estrogen exposure, in flathead minnows (Pimephales promelas) exposed to waterborne 17 beta-estradiol. Aquat. Toxicol. 40, 335-360.

Kumar, T.R., Wiseman, A.L., Kala, G., Kala, S.V., Mayzuk, M.M., Lieberman, M.W. 2000. Reproductive defects in gamma-glutamyl transpeptidase-deficient mice. Endocrinology 141, 4270-4277.

Livingstone, D. 1998. The fate of organic xenobiotics in aquatic ecosystems: quatitative and qualitative differences in biotransformation by invertebrates and fish. Comp. Biochem. Physiol. 120A, 43-49.

Lowry, O.J., Rosebrough, N.J., Farr, A.L., Randall, R.J., 1951. Protein measurements with folin phenol reagent. J. Biol. Chem. 193, 265-275.

Meucci, V., Arukwe, A., 2006. The xenoestrogen 4-nonylphenol modulates hepatic gene expression of pregnane $\mathrm{X}$ receptor, aryl hydrocarbon receptor, CYP3A and CYP1A1 in juvenile Atlantic salmon (Salmo salar). Comp. Biochem. Physiol. C. $142,142-150$.

Middaugh, D.P., Hemmer, M.J., Lores, E.M., 1988. Tetratological effects of 2,4dinitrophenol, 'produced water' and naphthalene on embryos of the inland silverside Menidia beryllina. Dis. Aquat. Org. 4, 53-65.

Monteiro, P., Reis-Henriques, M., Coimbra, J., 2000. Polycyclic aromatic hydrocarbons inhibit in vitro ovarian steroidogenesis in the flounder (Platichthys flesus L.). Aquat. Toxicol. 48, 549-559.

Pollino, C.A., Georgiades, E., Holdway, D.A., 2007. Use of the Australian crimsonspotted rainbowfish (Melanotaenia fluviatilis) as a model test species for investigating the effects of endocrine disruptors. Environ. Toxicol. Chem. 26, 2171-2178.

Pollino, C.A., Holdway, D.A., 2002a. Alteration in the reproductive potential of crimson-spotted rainbowfish (Melanotaenia fluviatilis) exposed to Bass Strait crude oil and dispersed crude oil. Environ. Toxicol. 17, 138-145.

Pollino, C.A., Holdway, D.A., 2002b. Toxicity testing of crude oil and related compounds using early life stages of the crimson-spotted rainbowfish (Melanotaenia fluviatilis). Ecotoxicol. Environ. Saf. 52B, 180-189. 
Pollino, C.A., Holdway, D.A., 2003a. Hydrocarbon-induced changes to the metabolic and detoxification enzymes of the Australian crimson-spotted rainbowfish (Melanotaenia fluviatilis). Environ. Toxicol. 18, 21-28.

Pollino, C.A., Holdway, D.A., 2003b. Reproduction of a laboratory-based population of the Australian crimson-spotted rainbowfish (Melanotaenia fluviatilis). Aust. J. Ecotoxicol. 9, 113-117.

Reichert, W.L., Varanasi, U., 1982. Metabolism of orally administered naphthalene in spawning English Sole (Parophrys vetulus). Environ. Res. 27, 316-324.

Steadman, B., Farag, A., Bergman, H., 1991. Exposure-related patterns of biochemical indicators in rainbow trout exposed to no. 2 fuel oil. Environ. Toxicol. Chem. 10, 365-374.

Stene, A., Lonning, S., 1985. Effects of short-term exposures to naphthalene, methyl- and hydroxynaphthalenes on 2 different embryonic stages of cod (Gadhus morhua L.). Sarsia 7, 279-285.
Thomas, P., 1990. Teleost model for studying the effects of chemicals on the female reproductive endocrine function. J. Exp. Zool. Suppl. 4, 126-128.

Thomas, P., Budiantara, L., 1995. Reproductive life history stages sensitive to oil and naphthalene in Atlantic Croaker. Mar. Environ. Res. 39, 147-150.

Tintos, A., Gesto, M., Míguez, J.M., Soengas, J.L., 2007. Naphthalene treatment alters liver intermediary metabolism and levels of steroid hormones in plasma of rainbow trout (Oncorhynchus mykiss). Ecotoxicol. Environ. Saf. 66, 139-147.

Weis, J.S., Weis, P., 1989. Effects of environmental pollutants on early fish development. Aquat. Sci. 1, 45-73.

Wu, R.S.S., Pollino, C.A., Au, D.W.T., Zheng, G.J., Yuen, B.B.H., Lam, P.K.S., 2003. Evaluation of biomarkers of exposure and effect in juvenile areolated grouper (Epinephelus areolatus) upon foodborne exposure to benzo[a]pyrene. Environ. Toxicol. Chem. 22, 1568-1573.

Zar, J.H., 1999. Biostatistical Analysis. Prentice-Hall, New Jersey. 